\title{
Thailand: The Financial System Ten Years after the Crisis
}

\author{
Ammar Siamwalla
}

\begin{abstract}
1 Introduction
When the bank of Thailand floated the baht on 2 July 1997 - and saw its value fall by more than half in eight months, the world naturally thought of it as primarily a currency crisis. But it is the massive failure of the financial system, the other half of the twin crises, that had a more profound impact and which wrought significant institutional changes to the economic system of the country.
\end{abstract}

The story of the events that led to the denovement of 2 July 1997 is well known, so we need merely to cover it in one short paragraph. ${ }^{1}$ Beginning in 1990 but accelerating in 1993, the Bank of Thailand engaged in a series of moves to liberalise the capital account. The control on foreign inward movements of capital was removed, and foreign lenders were allowed to lend money to Thai financial institutions and to Thai corporations in a regime with fixed exchange rates. Given the strength of the Thai economy prevailing in the early 1990s, these lenders found that lending to Thai companies and banks was quite profitable and carried little risk. As the economy heated up during the bubble that preceded the collapse (from about 1993), the Bank of Thailand began to tighten up interest rates. As could be expected, the only impact this policy had was to induce more money, mostly short-term, to flow in, with the result that Thai companies became heavily indebted in dollars. Worse, a substantial chunk of this dollar debt was intermediated by Thai banks, who borrowed short-term from foreign banks. By mid1995 total short-term external debt from the private sector plus the annual current account deficit exceeded the foreign exchange reserves of the Bank of Thailand. After that it was a matter of time before the speculators realised that the fixed exchange rate regime was no longer tenable. In November 1996, the first attack on the baht began, and after three waves of attack, it was all over. The Bank of
Thailand's net foreign exchange reserves were nearly exhausted, and the baht was devalued.

Underlying all of these developments and which propelled the economy towards ultimate collapse was the weakness of the keystone institutions in the Thai financial system, the commercial banks and finance companies, ${ }^{2}$ and concomitantly, the supervisory system of the central bank.

This article will examine the changes that occurred in the Thai financial system since 1997, and evaluate the performance of the economy that emerged. Because the financial system and its supervision were the central weakness and the focus of the post-crisis reforms - at least until the appearance on the scene of the Thaksin government, Section 2 dwells on the system's pre-crisis structure, which is followed by a discussion, in Section 3, of the reforms that took place. Section 4 looks at the expansion of the capital market, which has partially taken over the role of the banks as the source of funding for companies. Section 5 comments on post-crisis monetary and exchange rate policies and Section 6 concludes and suggests where further reforms are needed.

\section{The weakness of the pre-crisis financial system}

Before the crisis, 15 commercial banks dominated the scene with about 100 finance companies bringing up the rear. ${ }^{3}$ Flows of funds figures show them to be able to obtain about 60 per cent of household financial savings each year. ${ }^{4}$ These household savings were essential to supplement the capital needs of the rapidly growing incorporated enterprises, because they plough back only one-third of their incomes for investment. During the period 1993-6, these enterprises obtained a majority of their outside funding through short-term and longterm bank loans. Foreign saving of loans also 
Table 1 Source of net fund flows for incorporated enterprises 1993-6 (\%)

\begin{tabular}{lcccc}
\hline & 1993 & $\mathbf{1 9 9 4}$ & $\mathbf{1 9 9 5}$ & $\mathbf{1 9 9 6}$ \\
\hline Liquid financial assets & -21.5 & -7.1 & -6.0 & -9.2 \\
Short-term loans and bills & 26.0 & 15.8 & 20.6 & 23.3 \\
Trade credit & -0.2 & 2.2 & 1.1 & -0.9 \\
Long-term loans & 61.7 & 65.2 & 45.4 & 36.8 \\
Mortgages & 2.1 & 4.8 & 4.7 & 5.3 \\
Debentures & 4.0 & 9.2 & 4.7 & 0.6 \\
Hire-purchase debts & -13.3 & -10.2 & -8.5 & -12.6 \\
Foreign debts and claims & 32.5 & -13.8 & 20.2 & 38.6 \\
Share capital & 16.1 & 28.8 & 17.9 & 20.7 \\
Others & -7.2 & 5.1 & -0.1 & -2.6 \\
\hline Total net incurrence of liabilities & 100.0 & 100.0 & 100.0 & 100.0 \\
\hline Source Author's elaboration. & & & & \\
\hline
\end{tabular}

provided a significant source of funds to the firms, as well as indirectly through the banks (Table 1).

Given this pattern of the flow of funds, banks were highly vulnerable due to the classic reason of borrowing short and lending long. Thai banks, however, have been performing this function for decades, with relatively little mishap. In an earlier period, at the time when Thailand was primarily an agricultural exporter, banks were financing mostly short-term needs of the traders, and the problem of the maturity mismatch was not so severe. But as the country industrialised, the mismatch problem became severe, and during the bubble period, it was compounded by currency mismatch, because banks were intermediating by using dollars to finance many firms which were engaged in non-tradable activities, in particular, the property sector. ${ }^{5}$

The newly liberalised credit markets also compounded a chronic weakness of the Thai banking sector, which is its penchant for insider lending. Banking families had traditionally used credit from their banks to build up large business empires. To the extent that these were investments in real assets, and to the extent that the families had an interest in making productive investments, the long-term survival of this system was not threatened. The bank rate of failures was kept at about one per decade.
But during the atmosphere bubble of 1993-6, with unlimited money flowing in from overseas, a great deal of the money was diverted by bankers and borrowers to speculate in the property and stock markets. The failure of the Bangkok Bank of Commerce (BBC) in 1995 was a particularly notorious example of the sort of malpractices by the new breed of bankers.

The failure of the BBC also showed the weakness of the Bank of Thailand's supervision system. Aside from the question of the personal integrity of the personnel involved (a question that previously had never been raised as far as the central bank was concerned), there was also a structural problem with the design of the supervision system, in which forbearance was built in. The problems at the BBC had been lingering for well over a decade before they came to a head. Throughout, the central bank had not only shown extraordinary forbearance, but at various points had injected funds to shore it up, using the Financial Institutional Development Fund (FIDF) for the purpose. The FIDF was managed jointly by the central bank and the Ministry of Finance, with the bank having more de facto power. Further, the fund was set up under the Bank of Thailand Act and consequently, the paper would be guaranteed by the central bank itself. Thus, it turns out that the supervisory agency, i.e. the central bank, 
had access to unlimited funds from the money market to rescue itself from its own folly.

One should add at this point that throughout the period until August 1997, Thailand never had a formal system of deposit guarantee. However, the practice of the central bank in the past in dealing with problem banks had been to rescue them with zero impact on depositors; in many cases the resources for the rescue coming from FIDF. ${ }^{6}$

By the first half of 1997, the weakness of the banking sector was becoming obvious. In March, ten finance companies were told by the central bank to increase their capital, followed a few months later by the suspension of 16 finance companies (including the first ten that were told to increase their capital). In August 1997, 58 (out of some 91 remaining) more were suspended, and in November, all but two of these were closed down altogether. $A$ few more were closed in the following year. By the end of 1998, finance companies, whose deposits used to be as much as one-third of the commercial banks' funds, ceased to be a significant factor in the financial system. The year 1998 also saw the government's takeover of a number of smaller banks.

The collapse of the financial system was extremely costly for the Thai treasury. Totalling 1.4 trillion baht (the estimate being made as of May 2002), it constituted about 30 per cent of the GNP that year. Naturally, controversy surrounded the question of whether the Thai government (then working under an IMF programme) had taken the right course of action on the problems of the financial institutions, as well as on the method of disposal of their assets. While this question may lend itself to forensic investigations, a better question is to ask how to prevent such a collapse from happening in the first place, and if parts of the financial system had of necessity to be excised, how could this be effectively done?

\section{A radically different banking system}

Devastated by the crisis, the Thai banking system emerged from it with slightly less than half of the total deposits being in the state banks, much of it taken over during the reorganisation of the crisis. The surviving private banks realised that the old business model that served it well in the pre-crisis era was no longer viable, even in the long term.
In the short term - and it was a short term that lasted almost six years - lenders and borrowers alike were engaged in sweating out the overhang of debt accumulated during the bubble. This process took longer than was necessary. This is not surprising, given that the assets classified as non-performing touched 40 per cent for all banks at one point.

The two governments - Democrat (1997-2001) and Thai Rak Thai (2001-7) - had different approaches on the proper policies that the government should follow in facilitating the workout. The Democrat government relied on the reform of the bankruptcy law which was meant to speed up the workout process, which was itself left to the lenders and borrowers to work out for themselves. The Thai Rak Thai government decided to buy out the bad assets from the existing banks (except those that were already in the judicial process) and place them in the Thai Asset Management Corporation (TAMC), who would then oversee the workout, with the losses being shared between the lenders and the government. A point worth noting is that well over four-fifths of the acquired assets were from state banks.

Of course, the non-judicial arrangement of TAMC could easily lead to corruption. Thus far, no such charge has been made, which is not surprising as the procedures used have been singularly opaque, and very little information seems to have been supplied about the outcomes of its asset management.

As far as the long-term strategy is concerned, private banks are now extremely wary about lending to large businesses, although they have been expanding other fee-based services to those customers, such as cash management. They have been turning to consumer banking and have expanded businesses such as credit cards and mortgages. In this they have been following the trend of banking worldwide (Ghosh 2006).

Households are themselves increasingly moving away from banks towards shares and only 20-40 per cent of their financial savings are in the banks, as contrasted to over 60 per cent before the crisis, with much of the remainder going into share capital, mutual funds and government bonds.

Apart from these shifts by both savers and investors, banks are now also subject to much more stringent supervision. In particular, the definition of nonperforming loans has been tightened up considerably. 
'Evergreen' loans could no longer pass the central bank's audit. These changes have made lending transactions to businesses considerably less attractive.

From being an essential cog in the transfer from saving to investment, the banks' role in this intermediation has become increasingly peripheral, with the capital market taking up much of the decline. Nevertheless, it cannot be said the latter has completely taken over the role of the banks. Two observations will bear this out:

1 The investment/GDP ration is still in the mid20 per cent range, after being consistently in the 30 plus range in the early 1990 s and even before the bubble.

2 Banks have been having excess liquidity since 1999 and have not been able to unload this liquidity to good borrowers.

\section{The expansion of the capital market}

As banks have withdrawn from supplying capital to large firms, the latter have mostly turned to the capital markets to issue debentures and some share capital. The amounts raised by these means each year easily exceeded the increase in bank credit. For example, in 2006, credits from banks increased by 426.0 billion baht, while newly issued domestic securities from private corporations were as high as 852.7 million baht.

There are two additional observations that need to be made:

1 The capital market is still the preserve of large corporations, with small firms being effectively excluded. Although it needs to be added that Thailand has an active bill-of-exchange market of an unknown size, which appears to fill the needs of at least medium-sized firms.

2 During the post-crisis period, firms have been actively using their cash flow both to run-down their debts, and to make new investments. This has been the pattern in the past after every economic downturn.

\section{Monetary and exchange rate policies}

After the violent gyrations brought on by the crisis in 1997-8, the economy began to stabilise, albeit at a low level which persisted for a long period. With prices relatively stable, despite a drastic devaluation of the baht, the Bank of Thailand felt confident enough to shift its policy regime to inflation targeting, while retaining a (mostly) flexible exchange rate regime.

Having swung violently from a current account deficit of 8 per cent to a surplus of 12 per cent within three months, Thailand saw continual surpluses as it worked off its debt over the next seven years, while the baht slowly appreciated along with other Asian currencies until the last quarter of 2006.

Unfortunately, being a cleaner floater than the rest of Asia has its price. During the last quarter of 2006, as the betting in the currency markets was that the dollar would weaken, speculators found that pouring money into the baht (as against, say, the renminbi) was quite profitable, because the baht, being more flexible, appreciated more strongly than other Asian currencies, excluding the Philippine peso and the Indonesian rupiah.

There was also a problem with the baht in that its interest rate was somewhat higher than its neighbours. The Monetary Policy Committee held firm against lowering interest rates because it was tethered to its inflation target. Perceiving that the rapid ascent of the baht was destabilising the country's trade, and reluctant to expand the remit of its inflation targeting regime, the Bank of Thailand decided to control the inward flow of capital by using the Chilean device of requiring uncompensated reserves of 30 per cent on most transactions, including the use of non-resident baht accounts to purchase stocks and other debt instruments. Coming out of the blue, this played havoc with the stock market, which saw its index decline by 15 per cent in one day. The control measure has been softened somewhat, but foreign confidence has been severely affected, at least temporarily.

\section{Unfinished business}

There have been two positive policy developments since the crisis, but one of these is as yet incomplete, and the other remains untested under trying conditions.

The incomplete policy pertains to the question of ensuring the stability of the financial institutions. Much has been achieved in improving the quality of the supervision of the central bank. Both the central bank and the banks themselves have taken on board the idea that the central task in dealing with financial institutions is risk management. Unfortunately, while individual (private) banks have become more adept at 
this task, the policy framework has two very large gaps. One is the very large share of state banks in the industry. The risk posed by state banks is that despite the lessons learnt during the crisis, they still lend to politically connected individuals. Until these banks are privatised, risks with these banks will remain. The other gap is the blanket deposit guarantee adopted during the crisis in August 1997. This needs to be reformed, and at a time when there is not much risk of a run (such as now).

The untested policy is the inflation-targeting regime which the bank has adopted. Ever since its introduction, the stress from the demand side on inflation has been small. How the regime will survive under red-hot conditions, such as those that occurred

\section{Notes}

1 For a more extensive account of the events that led to the 2nd of July 1997 debacle, see Siamwalla et al. (2003).

2 Finance companies are near-banks that can accept deposits from the general public (there is a minimum amount to be deposited). The main difference is that they cannot issue cheques and therefore play no role in the payment system.

3 Bank deposits were about three-quarters of the deposits of both types of institutions.

4 'Household' in Thai financial accounts includes unincorporated enterprises.

5 Because the central bank required banks to balance their foreign exchange assets and

\section{References}

Ghosh, S.R. (2006) East Asian Finance: The Road to Robust Markets, Washington DC: The World Bank, The International Bank for Reconstruction and Development

Siamwalla, A.; Vajragputa, Y. and Vichyanond, P. (2003) 'Foreign Capital Flows to Thailand: during 1993-6, remains untested. One small problem is that the central bank is not legally independent. It is a small problem, because in the past, the central bank as an institution has enjoyed the trust and support of the population to a remarkable extent. That trust and support declined sharply during the period leading up to and immediately after the crisis of 1997. However, since then the bank has substantially recovered much of its lost prestige. Nevertheless, it has to be kept in mind that, even after the crisis, one of the governors was sacked. Indeed, the number of governors being sacked has become more frequent. It remains to be seen how it will fare when it becomes necessary 'to take away the punch bowl just as the party gets going', as an American central banker once remarked.

liabilities with the maximum imbalance permitted being 20 per cent of first tier capital, it would appear that banks should not have a severe problem of currency mismatch. Although the currency risk may have been minimised, given the activities of their customers, that risk may have been replaced by credit risk. For a further discussion on this point, see the final article by Griffith-Jones and Gottschalk in this IDS Bulletin.

6 Finance companies were allowed to fold with depositors taking a partial hit. The reason for the differential treatment was that banks are part of the payments system, whereas finance companies are not.

Determinants and Impact', in S. Griffith-Jones, R. Gottschalk and J. Cailloux (eds), International Capital Flows in Calm and Turbulent Times: The Need for New International Architecture, Ann Arbor: The University of Michigan Press 